\title{
MATERNAL IMMUNITY OF NATIVE CATTLE BREED VACCINATED WITH ATTENUATED MP-12 RIFT VALLEY FEVER VACCINE
}

\author{
IBRAHIM, A.M., T. A.SAID, EMAN M. SHALKAMY, \\ G. K. MOHAMMED AND H. A. M. AZAB \\ Veterinary Serum and Vaccine Research Institute,ARC,Ministry of Agriculture, Abbasia, Cairo
}

(Manuscript received 10 January 2011)

\begin{abstract}
The present study aimed to evaluate the immunity and abortagenicity and teratogenicity effect in vaccinated pregnant native cattle breed with $5 \log 10 \mathrm{TCID}_{50} /$ animal live mutagenized RVF MP-12 vaccine. The maternal immunity in its delivered calves was investigated by using serum neutralization test (SNT) and Enzyme Linked Immunosorbent Assay (ELISA). There was no body temperature elevation or any other RVF clinical signs, especially abortion or tratogenic changes in cows and their delivered calves neither after vaccination nor after parturition. The live attenuated MP-12 vaccine was also effective to induce immunity at protective level within 14 days till parturition. The immunity was detected early in all groups of delivered calves from 1st day till 2 months in group 1 (G1), 3 months in (G2) and (G3). The colostrum had antibodies for the first 3 days post-parturition. The vaccination of pregnant cattle at 2- 5 months of pregnancy was recommended.
\end{abstract}

\section{INTRODUCTION}

Rift Valley Fever (RVF) is an acute febrile arthropod-borne viral disease which has caused widespread epizootics through out Africa and most recently Asia. It is a zoonotic highly infectious disease, and highly fatal among new born animals in livestock with abortion in pregnant ewes and cows (Gerdes, 2002). In Egypt, the first record of RVF was during 1977 with high morbidity and mortality in sheep and cattle and with mortality in human (Meegan et al., 1979). RVF outbreaks have occurred in Egypt in the past 30 years claiming the lives of many individuals and causing enormous economic burdens in the livestock industry in the country. There have been sporadic human and animal cases during the inter-epizootic periods.

Food Agriculture Organization (FAO) (2007) stated that RVF cause major epidemics at irregular intervals of $5-35$ years.

One of the tools to control RVF disease is vaccination with inactivated RVF vaccine and RVF attenuated Smithburn vaccine (Shalkamy, 1995 \& Smithburn, 1949). To avoid the multiple doses of inactivated RVF vaccine and the probability of abortogenicity and teratogencity of attenuated RVF Smithburn vaccine, a recent new RVF vaccine variant has been developed by serially passaging a human virus isolate (Strain ZH548) in human diploid fibroblast cells in the presence of the mutagen 5- 
flurouracil (Caplen et. al., 1985). Possessing attenuation markers in all three segments, MP-12 has a very low probability of reversion in-vitro or in-vivo on the long run Morrill et at, (1997) showed that RVF mutagenic MP-12 vaccine protects the bovine and ovine dams and fetuses against virulent challenge and is safe and efficacious for use in neonatal calves and lambs. The vaccine proved to be immunogenic, non-teratogenic, non-abortogenic, and viremia was not detected (Moroill et al., 1997).

Abdel-Monem and Marwa ( 2007) recorded that MP-12 vaccine is safe and immunogenic for vaccination in cattle. Abu-Elmagd and Diana (2009) stated that MP12 vaccine is very promising regarding the preliminary results of immunogenicity for 10 months post-vaccination in cattle.

So, the objective of the present study is to investigate the immunogenicity of the live attenuated RVF MP-12 vaccine in pregnant native breed cows and their delivered calves.

\section{MATERIALS AND METHODS}

Twelve local breed (Balady) cows less than 3 years old were used in this study. The cows were tested to be free from RVF antibodies by SNT and ELISA. The cows were injected with $2 \mathrm{ml}$ of PGF2a I/M (Estrumate) for contraception .The cows were tested by bull teasing for heat detection and then inseminated artificially.

Ultrasound scanner was used for pregnancy diagnosis.

The synthetic prostaglandin F2a (PGF2a), (a product of Schering-Plough Company) was used for contraception of cows at a dose of $2 \mathrm{ml} \mathrm{I} / \mathrm{M}$.

MP-12 attenuated RVF virus vaccine strain ZH548 (supplied by NAMRU-3, Abbasia, Cairo) was used for vaccination. The dose of vaccine was $10^{5} \mathrm{TCID}_{50} /$ animal $\mathrm{S} / \mathrm{C}$.

Nine cows were vaccinated with $10^{5} \mathrm{TCID}_{50}$ /animal with MP-12 RVF vacine as follows:

\begin{tabular}{|c|c|c|c|}
\hline Animal Groups & $\begin{array}{c}\text { No. of } \\
\text { animals }\end{array}$ & $\begin{array}{c}\text { Time of vaccination during } \\
\text { pregnancy }\end{array}$ & $\begin{array}{c}\text { Date of parturition post } \\
\text { vaccination }\end{array}$ \\
\hline G1 & 5 & At $7^{\text {th }}$ month & $2^{\text {nd }}$ month \\
\hline G2 & 2 & At $5^{\text {th }}$ month & $4^{\text {th }}$ month \\
\hline G3 & 2 & At $2^{\text {nd }}$ month & $7^{\text {th }}$ month \\
\hline G4 (Control) & 3 & Inject with normal saline & $2^{\text {nd }}, 5^{\text {th }}$ and $7^{\text {th }}$ months \\
\hline
\end{tabular}

The vaccinated animals were kept in mosquito proof stable and observed daily for 21 days post-vaccination for any RVF clinical signs, and then observed till parturition. 
Serum samples from pregnant cows were collected before and after vaccination at zero, 7, 14, 21, 28, 45, 60, 90, 120, 150, 180 and 210 days. Serum samples were collected from newborn calves at 1, 5, 7, 30, 60 and 90 days.

Colostrum was collected from parturated cow at 1, 2 and 3 days post-parturition.

All the samples (sera and colostrum) were examined for detection of antibodies against RVF virus by SNT and ELISA.

The RVF virus strain ZH501 of titer $7.5 \log _{10} \mathrm{TCID}_{50} / \mathrm{m} 1$ was used for SNT.

The Serum neutralization test (SNT) was performed according to Office of International Epizootics (OIE) Manual (1996).

The RVF virus antigen prepared according to Elian and Botros (1997) was used for ELISA.

Anti-bovine IgG conjugated with horseradish peroxidase was used in ELISA test which was carried out according to Voller et al. (1976).

\section{RESULTS AND DISCUSSION}

RVF and its related research aspects represent a wide interesting and progressable field for veterinary scientists. It was found that Egypt is usually threatened by RVF outbreaks due to the RVF virus which is circulating currently or periodically in Africa. Moreover, the disease is zoonotic, highly infectious and highly fatal among new natal in livestock with abortion in pregnant ewes and cows with enormous economic losses. So, the need of effective, safe and efficient vaccine against RVF virus is of importance.

MP-12 live attenuated vaccine is one of these promising vaccines. The follow up of immunity and abortagenicity in vaccinated pregnant cows and the maternal immunity in their delivered calves were investigated.

The results showed that allover the study, there was no clinical signs of RVF especially viremia or abortion recorded in vaccinated dams, the delivered calves were free from any tratogenic advirses. 
Table1. Neutralizing indices (mean) of pregnant cow sera vaccinated with MP-12 RVF vaccine.

\begin{tabular}{|c|c|c|c|c|c|c|c|c|c|c|c|c|}
\hline \multirow{2}{*}{$\begin{array}{c}\text { Animal } \\
\text { groups }\end{array}$} & \multirow{2}{*}{$\begin{array}{c}\text { Pre- } \\
\text { vaccination }\end{array}$} & \multicolumn{10}{|c|}{ Days Post Vaccination (DPV) } \\
\cline { 3 - 14 } & 0.3 & 1.2 & 1.8 & 1.8 & 1.8 & 2.1 & 2.7 & & & & & \\
\hline G1 & 0.4 & 1.4 & 1.7 & 2.1 & 2.1 & 2.1 & 2.4 & 2.7 & 3.3 & & & \\
\hline G2 & 0.2 & 1.3 & 1.8 & 2.1 & 2.1 & 2.1 & 2.7 & 3.3 & 3.9 & 3.6 & 3.9 & 3.3 \\
\hline G3 & & & & & & & & & & & & \\
G4 & 0.3 & 0.3 & 0.2 & 0.3 & 0.4 & 0.3 & 0.3 & 0.4 & 0.5 & 0.4 & 0.3 & 0.3 \\
\hline
\end{tabular}

Note parturition occurred in G1 after 60 DPV, in G2 after 120 DPV and G3 after 210 DPV

Table 2. Neutralizing indices (mean) of new born calve sera delivered from dams vaccinated with MP-12 RVF vaccine.

\begin{tabular}{|c|c|c|c|c|c|c|}
\hline \multirow{2}{*}{ Calves groups } & \multicolumn{7}{|c|}{ Days post parturition } \\
\cline { 2 - 7 } & 1 & 5 & 7 & 30 & 60 & 90 \\
\hline G1 & 1.7 & 2.1 & 2.1 & 1.7 & 1.7 & 1.0 \\
\hline G2 & 2.1 & 2.7 & 2.1 & 2.1 & 1.7 & 1.5 \\
\hline G3 & 2.1 & 3.3 & 2.7 & 2.3 & 2.0 & 1.7 \\
\hline G4 (Control) & 0.3 & 0.7 & 0.5 & 0.7 & 0.4 & 0.5 \\
\hline
\end{tabular}

Table 3. Neutralizing indices (mean) of colostrum from dams vaccinated with MP-12 RVF vaccine.

\begin{tabular}{|c|c|c|c|}
\hline Cow groups & $1^{\text {st }}$ day & $2^{\text {nd }}$ day & $3^{\text {rd }}$ day \\
\hline G1 & 2.5 & 2.1 & 2.1 \\
\hline G2 & 3.0 & 2.7 & 2.1 \\
\hline G3 & 3.3 & 3.0 & 3.0 \\
\hline G4 (Control) & 0.3 & 0.7 & 0.3 \\
\hline
\end{tabular}

Table 4. RVF antibodies in dams serum vaccinated with MP-12 live attenuated RVF vaccine by ELISA.

\begin{tabular}{|c|c|c|c|c|c|c|c|c|c|c|c|c|}
\hline Animal & & \multicolumn{11}{|c|}{ O. D. Days Post Vaccination } \\
\hline groups & vaccination & 7 & 14 & 21 & 28 & 45 & 60 & 90 & 120 & 150 & 180 & 210 \\
\hline G1 & 0.002 & 0.183 & 0.190 & 0.201 & 0.209 & 0.228 & 0.291 & & & & & \\
\hline G2 & 0.002 & 0.176 & 0.189 & 0.189 & 0.231 & 0.261 & 0.265 & 0.281 & 0.291 & & & \\
\hline G3 & 0.001 & 0.181 & 0.189 & 0.193 & 0.269 & 0.268 & 0.261 & 0.291 & 0.310 & 0.331 & 0.371 & 0.344 \\
\hline $\begin{array}{c}\text { G4 } \\
\text { (Control) }\end{array}$ & 0.002 & 0.002 & 0.001 & 0.011 & 0.021 & 0.012 & 0.023 & 0.012 & 0.023 & 0.021 & 0.024 & 0.012 \\
\hline
\end{tabular}

O. D. = optical density Cut-off $=0.189$ 
Table 5. RVF antibodies in serum calves delivered from dams vaccinated with MP-12 live attenuated RVF vaccine by ELISA.

\begin{tabular}{|c|c|c|c|c|c|c|}
\hline \multirow{2}{*}{ Calves groups } & \multicolumn{7}{|c|}{ O. D. / Days post parturition } \\
\cline { 2 - 7 } & 1 & 5 & 7 & 30 & 60 & 90 \\
\hline $\mathrm{G} 1$ & 0.189 & 0.201 & 0.228 & 0.191 & 0.189 & 0.173 \\
\hline $\mathrm{G} 2$ & 0.196 & 0.231 & 0.261 & 0.192 & 0.189 & 0.166 \\
\hline $\mathrm{G} 3$ & 0.199 & 0.211 & 0.253 & 0.201 & 0.193 & 0.189 \\
\hline G4 (Control) & 0.021 & 0.012 & 0.023 & 0.012 & 0.023 & 0.021 \\
\hline
\end{tabular}

Table 1 showed the mean Neutralizing indices (NI) of pregnant cows vaccinated with $10^{5}$ PFU RVF MP-12 live attenuated vaccine. The protective level was detected at 14 days post-vaccination, and gradually increased to reach 2.7 in group (1) (third semester of pregnancy); the dams of this group parturated 60 days postvaccination. In group 2 (second semester of pregnancy); the level reached 3.3 at 120 days post-vaccination; the dams of this group parturated at 120 days post vaccination. The peak of the NI in dams group 3 (first semester of pregnancy) was at 120 days post-vaccination (3.9) and continued to be highly protective till the time of parturition (210 days post-vaccination). These results are in agreement with the results of Morrill et al. 1997, Abdel-Monem and Marwa 2007 and Abu-Elmagd, Diana 2009. They stated that the MP-12 RVF vaccine is immunogenic non-abortogenic in bovine dams.Also, Walker (1975) recorded that the NI 1.7 is a protective level, while, Pini et al. (1973) reported that NI 1.5 is a protective level.

Table 2 showed that the protective level in the delivered calves had been detected since the $1^{\text {st }}$ day post delivery till 2 months in group No.1, but, it continued till the $3^{\text {rd }}$ month post-delivery in calves of groups 2 and 3.This may be attributed to the high level of antibodies taken from mother. These results are in agreement with Tizard (2000) who stated that the maternal immunity in bovine was transmitted from dams to calves through colostrum and persisted for 2-4 months of calves age.

Table 3 showed that the antibodies in collected colostrum were high in percentage during $1^{\text {st }}$ three days post-parturition in all three groups of parturated dams. The NI ranged between 2.5-3.3. Tizard (2000) stated that the only way in transmission of maternal immunity in bovine is through colostrum.

It was clear from Table 4, that the optical density of vaccinated pregnant dams started to appear in positive level (cut-off 0.189 ) on $14^{\text {th }}$ day post-vaccination, while, Table 5 indicated that the antibodies in the calves were on the $1^{\text {st }}$ day of life. It seems that the results of SNT were in parallel to these of ELISA confirming each other and showing 
that the live attenuated MP-12 vaccine protected calves up to 3 months of age. These findings are in agreement with Morrill et al. (1997).

From the above results, we can calculate that the duration of maternal immunity in new born calves delivered from cows vaccinated with live attenuated MP12 vaccine lasts up to three months, and that vaccine has no abortogenic or teratogenic effect.We recommend that the best time of choice for vaccination of pregnant cattle with attenuated RVF MP12 vaccine will be at 2-5 months of pregnancy. 


\section{REFERENCES}

1. Abdel-Monem and F. M. Marwa. 2007. Study on attenuated Rift Valley Fever virus MP12 vaccine in cattle M. V. Sc. Thesis, Fac. Vet. Med. Cairo University.

2. Abu-Elmagd and Diana. M. 2009. Studies on Rift Valley Fever vaccines Thesis M. V. Sc.,, Fac. Vet. Med. Alexendria University.

3. Caplen, H., C. J. Peters and D. H. Bishop. 1985. Mutagen-directed attenuation of Rift Valley fever virus as a method for vaccine development. J. Gen. Virol., 66:2271-7.

4. Elian, K.A and B. Botros. 1997. Production and evaluation of RVF diagnostic antigens by ELISA technique.3rd Arab Vet. Med. Cong. March 22-26,1997 Cairo.

5. FAO 2007. Flare-up of Rift Valley Fever in the horn of Africa. Newsroomen Newsstories: 4 Jan 2007..www.fao.org/Newsroomen/news/2007

6. Gerdes G.H. 2002. Rift Valley Fever.Vet. Clin.North .Am.Food Anim Pract, : 549555.

7. Meegan, J. M., H. Hoogstraal and M. I. Moussa. 1979. An epizootic of RVF in Egypt in 1977.Vet. Rec,105 (6): 124-5.

8. Morrill J.C., C. A. Mebus and C. J. Peters. 1997. Safet of a mutagen-attenuated Rift Valley Fever virus vaccine in fetal and neonatal bovids. Am.J.Vet.Res, 58:1110-1114.

9. OIE M annual. 1996. Rift Valley Fever - virus neutralization,Chapter 2.1.8., page 104-105.

10. Pini, A., L.J. Lund and S. J. Davis. 1973. Fluorescent and neutralizing antibody response to injection by RVF. J. S. Afr. Z. Med. Ass., 44 (11): 161.

11. Shalkamy, M Ema. 1995. Studies on Rift Valley Fever vaccine inactivated with binary. Vet. Sc., Fac. Vet. Med., Cairo Univeristy.

12. Smithburn K.C. 1949. Rift Valley Fever : the neurotropic adaptation of virus and experimental use of this modified virus as a vaccine.Br. J. Exp. Path., 30: 1-16.

13. Tizard, I. R. 2000.Resistance to viruses. Vet. Immunol. College Vet. Med. Texas University.

14. Voller, A., D. E. Bidwell and A. Bartlett. 1976. Enzyme immunoassay in diagnostic medicine, theory and practice. Bull. World HIth. Organ., 53: 55-56.

15. Walker, S.J. 1975. Rift Valley Fever: A review committee on forgein animal diseases, United State of Animal Health Association, US Army Med., Bes. Inst. Inf. Dis., Fredrick, Maryland. 
المناعة المكتسبة من الام لسلالة الأبقار المحلية المحصنة بلقاح حمى الوادي

\section{المتصدع المستضعف MP12}

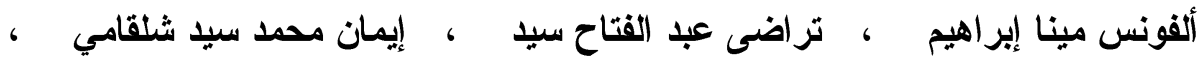

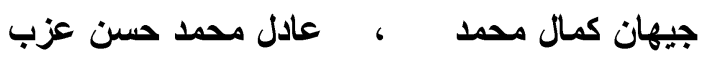

معرج بحوث الأمصال و اللقاحات البيطرية-مركز البحوث النراعية-وزارة الزراعة-الدقى-الجيزة

تهدف هذه الدراسة إلى تقييم المناعة و الإجهاض وتشوهات الأجنة في الأبقار العشار المحلية المحصنة بلقاح حمى الو ادي المتصدع المستضعف MP12 بجرعة $10^{5}$ TCID لكل حيو ان و المناعة الأمية في العجول المولودة منها باستخدام لكل من اختبارى التعادل المصلي و الإليز ا.وقد وجد أنه لم

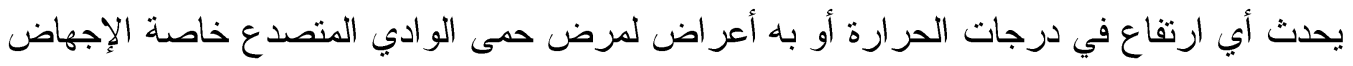

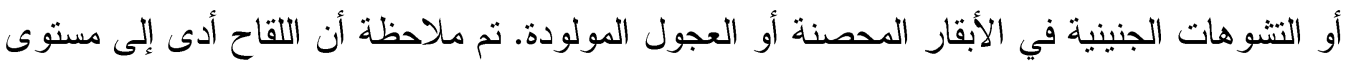
كاف للوقاية منذ 14 يوماً بعد التحصين وحتى الو لادة و يحتوي السرسوب على أجسام مناعية خلال

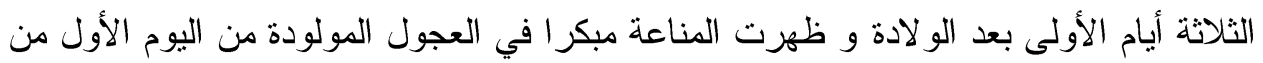

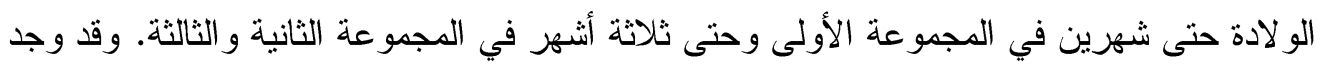
أن الوقت الأمثل لتحصين الأبقار العشار بهذا اللقاح هو عند 2- 2- 5 شهور من الحمل. 